\title{
Dampak Sosialisasi Kebijakan Keselamatan Dan Kesehatan Kerja Terhadap Pelaksanaan Keselamatan Dan Kesehatan Kerja
}

\author{
Hana Ike Dameria Purba ${ }^{1 *}$, Vierto Irennius Girsang ${ }^{1}$, Sylvia Maryance Siadari ${ }^{1}$ \\ ${ }^{1}$ Program Studi Kesehatan Masyarakat, Fakultas Farmasi dan Ilmu Kesehatan, Universitas Sari \\ Mutiara Indonesia \\ *Penulis korespondensi: Program Studi Kesehatan Masyarakat, Fakultas Farmasi dan Ilmu \\ Kesehatan, Universitas Sari Mutiara Indonesia, E-mail: purbahana@yahoo.com, Phone: +62- \\ 81-397850898
}

\begin{abstract}
ABSTRAK
Pada tahun 2017 terdapat 30 kasus kecelakaan kerja di lokasi penelitian yakni perusahaan pengolahan kelapa sawit. Tujuan penelitian ini untuk menganalisis Penerapan Kebijakan dan Perencanaan Kebijakan Keselamatan dan Kesehatan Kerja (K3) di sebuah perusahaan pengolahan kelapa sawit. Jenis Penelitian ini adalah kualitatif dengan pendekatan fenomenologi. Data dikumpulkan melalui wawancara mendalam dan observasi langsung. Informan dalam penelitian ini yaitu manajer (sekaligus Ahli K3) serta sekretaris K3. Hasil penelitian menunjukkan bahwa kebijakan K3 sudah ada tertulis, namun belum tersosialisasikan kepada seluruh elemen perusahaan. Perencanaan K3 telah dilakukan dengan pengumpulan data dan penentuan prioritas. Pengorganisasian dilakukan dengan membentuk organisasi P2K3. Penerapan K3, sosialisasi dan penyediaan alat pelindung diri nasih rendah dikarenakan dana yang minim. Evaluasi dan peninjauan belum terlaksana secara sempurna. Rekomendasi bagi pihak manajemen untuk lebih memperkuat komitmen melalui penyediaan anggaran khusus $\mathrm{K} 3$, penyediaan personil P2K3 yang memenuhi syarat, disosialisasikannya kebijakan K3 kepada seluruh jajaran manajemen, karyawan dan pengunjung perusahaan.
\end{abstract}

Kata Kunci

: Kecelakaan Kerja, Program K3, Organisasi P2K3

\section{PENDAHULUAN}

Sistem Manajemen Keselamatan dan Kesehatan Kerja (SMK3) merupakan suatu upaya yang wajib dilakukan untuk mengatur dan menjadi acuan dalam mencegah kecelakaan dan penyakit akibat kerja di tempat kerja. SMK3 merupakan bagian yang tidak terpisah dari sistem perlindungan tenaga kerja. Dengan adanya SMK3, kecelakaan dan penyakit akibat kerja dapat diminimalisasi. ${ }^{1}$ Selain itu pekerja juga dapat terhindar dari risiko moral serta memiliki tempat kerja yang aman dan efisien. ${ }^{2}$ Tempat kerja tersebut diharapkan dapat menciptakan suasana kerja yang produktif. ${ }^{3}$

Penetapan kebijakan K3 merupakan hal mendasar dan wujud nyata komitmen perusahaan untuk melaksanakan SMK3. Penetapan kebijkan K3 juga merupakan bentuk dari kesediaan perusahaan untuk menjadikan K3 sebagai bagian dari aktifitas perusahaan yang tidak dapat dipisahkan. Setiap perusahaan yang telah memiliki kebijkan K3 diharapkan dapat menuangkan kebijakan tersebut kedalam perencanaan-perencanaan sebagai bentuk dari tindak lanjut komitmen perusahaan terhadap pelaksanaan kebijakan. Perencanaan yang telah disusun diharapkan dilaksanakan setiap hari dan berkelanjutan sehingga dampak dari kebijakan tersebut dapat 
dirasakan oleh seluruh karyawan dan perusahaan. ${ }^{4}$ Namun, dilain sisi ditemukan bahwa penerapan kebijakan K3 diperusahaan masih rendah. Penelitian terdahulu menunjukkan bahwa pemenuhan elemen kebijakan K3 hanya sebesar 37.5\%. ${ }^{5}$ Dilain sisi penerapan kebijakan K3 juga masih kurang didukung oleh regulasi-regulasi pemerintah daerah. Akibatnya penerapan kebijakan K3 tidak mendapatkan topangan yang kuat dari pemerintahan daerahnya.

Wilayah penelitian tersebut merupakan salah satu perusahaan yang sudah menerapkan SMK3 sejak tahun 2016. Berdasarkan hasil wawancara dan pemantauan awal yang dilakukan peneliti di lokasi penelitian ditemukan bahwa masih banyak karyawan yang belum memahami kebijakan dan perencanaan terkait K3 yang ada diperusahaan tersebut meskipun kebijakan K3 telah dibuat. Selain itu ditemukan bahwa mayoritas karyawan masih jarang menggunakan Alat Pelindung Diri (APD) pada saat bekerja. Berdasarkan data awal yang peneliti dapatkan pada saat observasi awal ditemukan bahwa pada tahun 2017 ditemukan 30 kasus kecelakaan kerja dalam satu tahun tersebut. Adapaun kecelakaan kerja yang sering terjadi pada saat karyawan bekerja dilapangan antara lain tertimpa pelepah sawit dan terkena alat pemotong rumput secara manual. Oleh karena itu peneliti bermaksud untuk melakukan analisis terkait dengan pelaksanaan kebijakan dan perencanaan K3 di perusahaan tersebut. Hasil dari penelitian ini diharapkan dapat memberikan masukkan dalam pengembagan kebijakan dan perencaan K3 di perusahaan tersebut.

\section{METODE}

Penelitian ini menggunakan metode penelitian kualitatif dengan pendekatan fenomenologi untuk menganalisis penyebab tingginya angka kecelakaan kerja dan kurangnya kesadaran para pekerja menggunakan APD pada saat bekerja dari segi penerapan kebijakan dan perencanaan K3. Penelitian dilaksanakan di suatu perusahaan pengolahan kelapa sawit yang telah menerapkan Sistem Manajemen K3 sejak tahun 2016. Pengumpulan data penelitian hanya dilakukan pada jam kerja yaitu pada jam 08.00 - 12.00 WIB kemudian dilanjutkan pada jam 13.00 - 18.00 WIB. Informan penelitian ini adalah manager perusahaan dan sekretaris K3 yang dipilih secara purposive sampling. Instrumen dalam penelitian ini adalah peneliti sendiri, panduan wawancara, dan observasi langsung. Data penelitian yang dikumpulkan yakni data primer yang diperoleh dari hasil observasi di lokasi penelitian dan wawancara dengan manager dan sekretaris K3. Data sekunder berupa struktur organisasi, standar/prosedur dan peraturan mengenai SMK3, dan daftar APD yang digunakan di lokasi penelitian serta studi kepustakaan yang digunakan sebagai data pendukung. Variabel penelitian ini adalah sistem manajemen keselamatan dan kesehatan kerja yang meliputi kebijakan K3 dan perencanaan K3 yang terdiri dari hazard identification, risk assasement, risk control (HIRARC), persyaratan legal serta objektif dan program K3. Pelaksanaan penelitian diawali dengan survei lokasi untuk meninjau kasus-kasus yang terjadi di proyek selanjutnya merumuskan latar belakang penelitian, masalah penelitian dan tujuan penelitian. Kemudian melakukan studi kepustakaan yang digunakan sebagai bahan dan pedoman untuk penelitian ini. Tahap kedua yakni pengumpulan data seperti survei lokasi untuk mengamati apakah perusahaan memenuhi syarat untuk dijadikan lokasi penelitian serta melakukan proses perijinan, melakukan wawancara mendalam (indepth interview) kepada pihak yang bertanggung jawab dalam penerapan SMK3 untuk mendapatkan keterangan yang mendukung dalam penelitian ini, melakukan observasi dalam arti melakukan pengamatan secara langsung mengenai penerapan SMK3, mengumpulkan data dan dokumen mengenai pedoman/standar dan peraturan-peraturan mengenai SMK3 yang diterapkan di tempat kerja serta mengadakan studi kepustakaan sebagai data pendukung. Untuk menetapkan keabsahan data dilakukan menggabungkan dari berbagai 
teknik pengumpulan data dan sumber data yang telah ada. Metode analisis data dilakukan dengan cara menyusun, membahas dan mengevaluasi data-data dan hasil wawancara/observasi mengenai SMK3 di tempat kerja. Selanjutnya diadakan studi kepustakaan yang digunakan sebagai data pendukung. Setelah seluruh data diperoleh maka hasil wawancara dicatat dan dibuat transkipnya. Transkip wawancara dibuat kata demi kata dengan memisahkan kata, frase, atau kalimat yang akan diolah dan yang tidak berhubungan dengan pernyataan penelitian. Setelah itu dilakukan reduksi yankni dengan proses pemilihan, pemusatan, perhatian, pengabstrasian dan pengtransformasian data kasar dari lapangan. Proses ini berlangsung pada saat penelitian dilakukan, dari awal sampai akhir penelitian. Dalam proses reduksi ini penelitian mencari data yang benar - benar valid. Setelah data direduksi, maka langkah selanjutnya adalah penyajian data. Penyajian data yaitu mengumpulkan data atau informasi secara tersusun, yang memberi kemungkinan adanya penarikan kesimpulan dan pengambilan tindakan. Data yang sudah ada disusun dengan menggunakan teks yang bersifat naratif, selain itu bisa juga bersifat matriks, grafik, dan chart. Penyajian data dilakukan dengan alasan supaya peneliti dapat menguasai data dan tidak tenggelam dalam tumpukan. Selain itu juga supaya peneliti mudah dalam memahami yang telah terjadi dan dapat merencanakan apa yang akan dilakukan selanjutnya. Verifikasi merupakan rangkaian analisis data puncak. Kesimpulan dalam penelitian kualitatif membutuhkan verifikasi selama penelitian berlangsung. Verifikasi dimaksudkan untuk menghasilkan kesimpulan yang valid. Oleh karena itu, ada baiknya sebuah kesimpulan ditinjau ulang dengan cara memverifikasi kembali catatan - catatan selama penelitian dan mencari pola, tema, model, hubungan dan persamaan untuk diambil sebuah kesimpulan. Setelah itu peneliti melakukan triangulasi teknik yaitu untuk menguji kredibilitas data dengan cara mengecek data dengan sumber yang sama dengan teknik yang berbeda (wawancara, observasi, dan dokumentasi). Setelah di triangulasi kemudian dilakukan penyajian data berupa teksnaratif, matrik, jaringan dan bagan. Data - data yang telah dikumpulkan, direduksi dan disajikan dengan cara yang mudah dipahami, kemudian ditarik suatu kesimpulan berdasarkan pengamatan yang menyeluruh dari data - data tersebut.

\section{HASIL DAN PEMBAHASAN}

Informan penelitian ini adalah General Manajer PKS Perusahaan sebagai reponden pengganti direktur yang sedang menjalankan tugas di luar kota. General Manajer dipilih sebagai informan sebab dianggap banyak mengetahui masalah K3 (Keselamatan dan Kesehatan Kerja) dan merupakan bagian yang membawahi P2K3 Perusahaan. Informan kedua adalah sektretaris K3 yang dangkat oleh direksi Perusahaan dimana informan tersebut bertugas sebagai penanggung jawab dokumen SMK3 diperusahaan perusahaan.

Komitmen manajemen Perusahaan dalam penerapan K3 diwujudkan dengan membentuk Struktur Organisasi P2K3. Komitmen dalam penerapan Keselamatan dan Kesehatan Kerja terlah tertulis dan ditandatangani oleh direktur Perusahaan, namun belum sepenuhnya berjalan dengan efektif. Berdasarkan pernyataan pihak pengelola, hal ini masih dalam persiapan. Komitmen juga diwujudkan dalam bentuk penyediaan anggaran khusus untuk penerapan keselamatan dan kesehatan kerja dan personil-personil yang khusus menangani masalah-masalah K3. Namun dana yang disediakan masih minim.

Bukti terbentuknya K3 di Perusahaan tersebut adalah dengan dikeluarkannya SK oleh Direktur Perusahaan tentang struktur kepengurusan K3 yang ditetapkan Perusahaan pada Bulan September Tahun 2017. Terbentuknya panitia pelaksana P2K3 tersebut merupakan bukti bahwa pihak Pimpinan Perusahaan telah berkomitmen untuk menerapkan K3 di Perusahaan. Namun, jika dilihat dari personil yang mengisi struktur organisasinya, belum dapat dianggap memenuhi syarat. 
Orang-orang yang terlibat didalam P2K3 tidak ada yang berlatar belakang pendidikan khusus mengenai Keselamatan dan Kesehatan Kerja, sehingga pengetahuan mereka tentang K3 sangat minim.

Kebijakan K3 di Perusahaan dapat diketahui dari jawaban responden ketika ditanyakan apakah perusahaan memiliki komitmen dalam menerapkan keselamatan dan kesehatan kerja sebagai berikut:

“.....iya, perusahaan memiliki komitmen dan kebijakan K3, dimana manager menetapkan organisasi P2K3 sesuai dengan stuktur organisasi. Dan dalam kebijakan K3 perusahaan melakukan penilaian kerja setiap karyawan dan tindak lanjut pelaksanaan K3 sesuai yang tertera didokumen SMK3 perusahaan. Memang masih baru menerapkan SMK3 dan masih belum rampung semuanya dan juga Dana yang masih minim, sehingga sarana dan prasarana belum rampung semua.. Sehingga kebijakan dan komitmen K3 masih membutuhkan pembenahan lagi... "( $\left.R_{1}\right)$

“...Ada, karenakan gimana y, memang lagi di rencanakan. Komitmen kebijakan K3 dibentuk oleh manajer kami yang selaku ahli K3, beliau yang menentukan struktur organisasi P2K3. Perencanaan kedepannya masih ada lagi, hanya saya lagi direncanakan, cuman semuanya y terhalang oleh dana. Intinya ada komitmen kebijakan K3 dimana akan menentukan sertifikat ISPO yaitu bagian pengendalian mutu minyak perusahaan ini....." $\left(R_{2}\right)$

Pihak yang terlibat dalam proses pembentukan kebijakan K3 di perusahaan tersebut terdiri dari Manajer dan ahli K3, Direktur dan direksi dari pusat dan karyawan yang ditunjuk sebagai sekretaris K3. Hal tersebut sesuai dengan pendapat Informan sebagai berikut:

“...Banyak yang terlibat dalam pembentukan kebijakan K3 saya sendiri sebagai manajer dan ahli K3 terlibat dalam pembentukan kebijakan K3, direktur atau direksi dari pusat dan salah satu karyawan dimana dia ditunjuk sebagai sekretaris $K 3$ diperusahaan ini...." $\left(R_{1}\right)$

“...Semuakan dari direksi, kantor pusat, managernya ikut, ahli K3 Umum ikut juga, udah gitu sekretaris K3. Setiap Mapoli Raya ini ngak satu PT gitu, sebenarnya dia Mapoli Raya Group. Ada sekitar 12 (dua belas) PT. Ada anak mapoli raya gitu. Jadikan masing-masing nanti anak perusahaan ini punya sekretaris $K 3$ yang sudah dilakukan pelatihan atau tersertifikasi. Kebetulan sekretris K3 adalah saya...” $\left(R_{2}\right)$ berikut:

Pendapat informan mengenai sasaran/target tujuan K3 di Perusahaan adalah sebagai

“...Sasaran atau target tujuan K3 ada tertera di dokumen SMK3 perusahaan. Sasaran yang ingin dicapai perusahaan untuk mencegah dan mengurangi kecelakaan dan penyakit akibat kerja serta terciptanya tempat kerja yang aman, efisien dan produktif..." $\left(R_{1}\right)$

“...Sarannyakan sudah jelas di buat di SOP ISP, agar mencegah dan mengurangi kecelakaan kerja dan penyakit akibat kerja serta terciptanya tempat kerja yang aman, 
efisien dan produktif. Kalau sudah amankan, jelas karyawan kan enak kerjanya. Samasama enaklah gitu kerjanya..." $\left(R_{2}\right)$

Pendapat Informan mengenai keterlibatan organisasi dalam proses perencanaan berbagai sumber daya yang mendukung kegiatan K3 adalah sebagai berikut:

“...Tentu ada keterlibatan saya dalam proses perencanaan K3 baik dalam bentuk sumber daya agar K3 berjalan dengan baik sumber daya tersebut adalah saya sebagai ahli K3 umum diperusahaan ini, pertama dalam melakukan suatu kegiatan tanpa didukung sumberdaya dalam bentuk dana tidak akan berjalan sama sekali. Sehingga perusahaan harus menyediakan anggaran, kemudian menyediakan tenaga kerja yang berkualitas sarana lainnya yang diperlukan dibidang $K 3 \ldots$..” $\left(R_{1}\right)$

“...Pasti adalah keterlibatan saya disini dalam proses perencanaan Kebijakan di perusahaan ini, termasuk juga manajernya dan juga direksi atau direktur. Dan sumberdaya yang mendukung berupa dengan dilakukan pelatihan K3 kepada saya, karena saya kan ditunjuk sebagai Sekretaris K3, sedikit-sedikitlah saya tahu tentang K3 apalagi tentang laporan K3 karnakan saya sudah dilatih, atau ikut pelatihan. Agar kegiatan K3 diperusahaan ini berjalan dengan baik... " $\left(R_{2}\right)$

Pendapat Informan tentang proses pembentukan kebijakan K3 di perusahaan ini adalah sebagai berikut:

“...Proses pembentukan K3 membutuhkan proses yang panjang sekali. Dalam proses pembentukan kebijakan K3 kami harus, menetapkan struktur organisasi $P 2 K 3$, menyediakan anggaran kegiatan $K 3$, menetapkan personel yang mempunyai tanggung jawab dalam penanganan keselamatan dan kesehatan kerja, membuat bentuk kebijakan diperusahan, bentuk kebijakannya seperti penyediaan alat pelindung diri, sanksi bagi karyawan yang melanggar aturan..." $\left(R_{1}\right)$

"Proses pembentukan Kebijakan K3 di perusahaan inisudah direncanakan mulai dari than 2016 kemarin y. dan baru-baru ini saja di laksanakan, dibentuklah struktur organisasi K3 dan P2K3, da nada juga anggota yang ditetapkan sesuai dengan tugas masing-masing. Contonya seperti bagian pemadan kebakaran dan dibagian produksi ditetapkan penanggung jawabnya..." $\left(R_{2}\right)$

Pendapat informan pada pelaksanaan kebijakan K3 di perusahaan adalah sebagai berikut: “....Pelaksanaan K3 di perusahaan ini masih belum efektif. Dikarenakan perusahaan ini masih baru saya menerapkan SMK3 dan masih banyak dalam proses perencanaan. Sehingga masih butuh pembenahan yang lebih dalam lagi..." $\quad\left(R_{1}\right)$

"Namanya juga baru ditetapkannya, masih banyak yang belum rampung, jadi masih kurang pelaksanaan kebijakan $\mathrm{K} 3$ disini... " $\left(R_{2}\right)$

Pendapat Informan tentang kendala yang dihadapi dalam melaksanakan kebijakan K3 adalah sebagai berikut:

“... Banyak kendala yang dihadapi dalam melaksanakan kebijakan K3, apa lagi ini masih baru diterapkan. Kendala yang sangat berpengaruhi adalah dana. Perencanaan 
K3 diperusahaan ini sudah berjalan selama tiga tahun hanya saya baru diterapkan, karena dana yang sangat minim. Kita tahu semua kegiatan tidak akan berjalan dengan baik jika dana tidak ada, kedua, karyawan, masih banyak karyawan yang belum paham apa itu K3, sehingga saya sebagai manajer atau ahli K3 memerintahkan anggota jajaran saya untuk terus melakukan penyuluhan atau sosialisasi K3 kepada karyawan agar berjalan dengan efektif semuanya..." $\left(R_{1}\right)$

“...Pertama Baget, , yang kedua individu y lah y kan, karena untuk menerapkan K3 itukan lebih banyak kita komunikasikan atau himbauan. Memberitahukan mana yang harus dilakukan sesuai dengan SOP dan mana yang benar-benar harus berhati-hati dalam melakukannya. Jadi kendala yang paling susah adalah bagi pekerja, banyak pekerja dimana mereka ada yang bilag tidak nyaman memakai APD pada saat bekerja. Atau membuat lambat pekerjaan mereka..." $\left(R_{2}\right)$

Pendapat Informan tentang manfaat yang dirasakan telah terlaksana kebijakan K3 adalah sebagai berikut:

“...Pasti ada manfaat yang dirasakan baik saya secara pribadi maupun karyawan yang bekerja disini. Terutama karyawan ya, mereka lebih merasa aman pada saat bekerja, kualitas produksi perusahaan akan semakin meningkat..." $\left(R_{1}\right)$

"Banyaklah manfaat yang dirasakan kami selaku pekerja, terutama karyawan yang bekerja dilapangan. Mereka merasa lebih nyaman bekerja, dan meningkatkan produksi minyak di PT ini walaupun masih belum semua terjalankan, tetapi manfaatnya sudah dirasakan sedikit demi sedikit.." $\left(R_{2}\right)$

Pembagian tugas secara jelas dengan menetapkan porsenil dalam struktur organisasi K3 dapat meminimalisir kecelakaan kerja di perusahaan. Beberapa pendapat informan mengenai cara meminimalisir kecelakaan kerja adalah sebagai berikut:

“...Saya dan struktur organisasi yang terkait didalam organisasi K3 adalah, disini dibuat rambu-rambu K3 terutama di bagian produksi. Karena disinikan PKS. Sebagai contohnya pekerja boiler, perusahaan memberikan baju sarung tangan untuk mengguramgi panas dari mesin boiler agar tidak terjadi kecelakaan kerja. Iya contohnya, memberikan APD kepada pekerja, agar pekerja aman dan nyaman pada saat bekerja..." $\left(R_{1}\right)$

“...Dengan memasang rambu-rambu K3 y, kemudian memberikan APD kepada pekerja khususnya didaerah produksi. Merekakan lebih rentan kena bahaya..." $\left(R_{2}\right)$

Pendapat Informan tentang pengambilan keputusan terhadap pelaksanaan penerapan dan perencanaan K3 adalah sebagai berikut:

“...Saya dan sebagaian jajaran bahkan direksi pada saat mengambil keputusan pada kebijakan K3 ini dilakukan secara bersama-sama. Melalui rapat bersama dulu, mengeluarkan pendapat masing-masing, kemudian kita lakukan musyawarah untuk memberikan keputusan yang baik untuk kebijakan K3 pdi perusahaan Mapoli Raya ini...." 
“...Dilakukan secara rapat untuk mengambilan keputusan secara bersama-sama y. Tidak pernah disini mengambil keputusan dengan secara pribadi y...”

$\left(R_{2}\right)$

Suatu Program atau kegiatan tidak akan berjalan dengan baik jika peninjauan ulang tidak dilakukan. Pendapat informan tentang peninjauan ulang kebijakan K3 dan Kapan dilakukan peninjauan ulang kebijakan K3 adalah sebagai berikut:

“...Iya dilakukan peninjauan ulang untuk membandingkan, ada tidak kemajuan produksi setelah diterapkannya SMK3 dan untuk membandingkan kesejahteraan pekerja. Peninjauan ulang dilakukan setiap triwulan, karena perusahaan melakukan pelaporan setiap triwulan. Disitulah kami melakukan peninjauang ulang sekaligus..."

$\left(R_{1}\right)$

“...Secara triwulan atau pertiga bulan dilakukan peninjauan ulang, disaat kami melakukan laporan triwulan P2K3..." $\left(R_{2}\right)$

Didalam pedoman penerapan SMK3 yang tertera di dalam Peraturan Pemerintah Nomor 50 Tahun 2012 Kebijakan K3 adalah suatu pernyataan tertulis yang ditandatangani oleh pengusaha dan atau pengurus yang memuat keseluruhan visi dan tujuan perusahaan, komitmen dan tekad melaksanakan K3, kerangka dan program kerja yang mencakup kegiatan perusahaan secara menyeluruh yang bersifat umum atau operasional.

Komitmen yang nyata dari pihak pimpinan dapat terwujud dengan penyediaan anggaran khusus untuk pelaksanaan program K3. Sebab mustahil suatu program dapat terlaksana tanpa adanya anggaran. Oleh sebab itu, penting bagi pihak manajemen perusahaan untuk mengkomunikasikan kepada seluruh karyawan perusahaan untuk bersama-sama berkomitmen menerapkan K3 di perusahaan ini. Sesuai dengan pedoman penerapan SMK3 yang dikeluarkan oleh pemerintah dalam PP No 50 Tahun 2012 yang menyatakan bahwa Komitmen di wujudkan dalam bentuk kebijakan tertulis, jelas dan mudah dimengerti serta diketahui oleh seluruh karyawan.

Untuk mencapai hasil yang diinginkan, maka harus dilakukan perencanaan yang baik dalam identifikasi bahaya, penilaian risiko dan pengendalian bahaya. Pendapat informan mengenai penentuan konteks untuk mengetahui potensi bahaya (Risiko Kesehatan Kerja, Kebakaran, Hygiene, dll) yang dapat menimbulkan efek terhadap kesehatan dan keselamatan karyawan adalah sebagai berikut:

“...Iya, kami selalu menentukan konteks bahaya. Jika tidak bisa menentukannya kita tidak akan mengetahui cara untuk mengurangi potensi bahaya atau bahkan untuk menghindar dari potensi bahaya yang terjadi lapangan... " $\left(R_{1}\right)$

"Dilakukan penentuan bahaya pekerjaan para pekerja. Supaya kami sebagai pihak penanggung jawab mengetahui bagaimana cara pengendalian bahaya di lapangan..." $\left(R_{2}\right)$

Pendapat Informan mengenai teknik menentukan potensi bahaya adalah sebagai berikut: “....Dengan menggunakan metode HIRARC. Disitulah kita merincikan sumber bahaya apa yang saja yang terjadi, efek yang akan dialami dan cara pengendaliannya. Dengan 
metode tersebut. Sehingga perusahaan dapat memperkecil angka kecelakaan kerja..." $\left(R_{1}\right)$

“...Ada teknik menentukannya, sesuai dengan dilaporan triwulan P2K3, kalau ngak salah metodenya HIRARC. Disitu dijelaskan bentuk bahayanya, efeknya, tingkat keparahannya, sering atau tidaknya terjadi dan pengendaliannya bagaimana caranya..." $\left(R_{2}\right)$

Pendapat informan mengenai proses penyusunana penilaian bahaya pada aktivitas kerja yang akan dilakukan adalah sebagai berikut:

“...Tadikan sudah saya jelaskan juga, bahwa penyusunan potensi bahaya dilakukan dengan metode HIRARC dan dilakukan pelaporan per tiga bulan, dan sesuai dengan dokumen SMK3 adanya standart penilaian risiko... " $\left(R_{1}\right)$

“...Melalui pelaporan kecelakaan kerja sekali tiga bulan atau per triwulan dan adanya teknik-teknik dengan standart penilaian risiko yang tertera didokumen $S M K 3 \ldots$... $\left(R_{2}\right)$

Pendapat Informan Mengenai memastikan bahwa pekerjaan tersebut aman dan dapat dilakukan aktivitas kerja adalah sebagai berikut:

“....Setelah dilakukan penilaian bahaya atau menentukan potensi bahaya setiap pekerjaan yang ada di perusahaan ini, dan kemudian dilakukan pengendalian. Berarti jika telah dilakukan pengendalian pekerjaan tersebut telah aman dilakukan..." $\left(R_{1}\right)$

“...Seperti yang saya bilang tadikan mbak, pertama mengenali dulu bahaya pekerjaan, kedua disitulah kita menentukan dampaknya dan tingkat keparahannya, setelah itu pengendaliannya. Kalau sudah aman atau dapat dikurangi kecelakaan kerja berarti pekerja sudah aman melakukan pekerjaan tersebut..." $\left(R_{2}\right)$

Pendapat Informan mengenai penentuan risiko yang terjadi, digunakan sebagai bahan untuk analisis dan evaluasi serta menentukan langkah atau strategi pengendalian adalah sebagai berikut:

“....Ya, dari hasil penentuan tersebut, kami jadikan sebagai acuan untuk mengevaluasi semua kebijakan K3 yang telah ditentukan di perusahaan ini. Evaluasi tersebut sebagai bahan, benar tidaknya atau sudahkah berjalan dengan baik K3 di perusahaan ini. Dan para karyawan apakah sudah paham bahwa setiap pekerjaan yang mereka lakukan memiliki risiko yang tinggi..." $\left(R_{1}\right)$

“...Iya dilakukan sebagai evaluasi untuk lebih baik agar kebijakan-kebijakan K3 yang ditelah diterapkan berjalan dengan baik, dan memastikan bahwa karyawan disini sudah tahu tentang K3 perusahaan ini..." $\left(R_{2}\right)$

Perencanaan K3 disetiap perusahaan penting dilakukan mengingat banyaknya hal yang harus dilakukan, sehingga melalui perencanaan yang baik semuanya dapat terlaksana. Tanpa perencanaan K3 yang baik akan sulit mengidentifikasi dan melaksanakan program yang benarbenar harus diprioritaskan untuk dilaksanakan. 
Ditinjau dari pedoman SMK3 menurut PP No 50 Tahun 2012, ditetapkan bahwa perencanaan K3 yang sesuai dengan persyaratan harus mempertimbangkan hasil penelaah awal, identifikasi potensi bahaya, penilaian dan pengendalian risiko, kemudian merumuskan suatu program dengan tujuan yang jelas.

Dalam pembentukan Program K3 harus dilakukan berdasarkan persyaratan yang sesuai dengan undang-undang. Pendapat Informan mengenai kapan dilaksanakan peraturan dan program K3adalah sebagai berikut:

“...Terlaksananya SMK3 di perusahan ini masih baru. Hanya perencanaanya telah dilakukan pada tahun 2014. Pelaksanaannya baru saja. Sehingga masih banyak perbaikan yang harus dilakukan... " $\left(R_{1}\right)$

"Perencanaan SMK3 telaah dilakukan sejak 4 tahun yang lalu, cuman baru 10 bulan ini dilaksanakan, masih banyak yang belum terlaksana kurang efektif... " $\left(R_{2}\right)$

Pendapat Informan mengenai penerapan K3 sesuai dengan undang-undang keselamatan kerja untuk menjamin para pekerja saat bekerja adalah sebagai berikut:

“...Iya ada ditetapkan undang-undangnya. Berdasarkan Peraturan Pemerintah No.50 tahun 2012. Dan perusahaan juga sudah mulai menetapkan sanksi kepada pekerja yang melanggar aturan kerja sesuai dengan lokasi pekerjaan..." $\left(R_{1}\right)$

“...Ada Undang-Undang keselamatan kerjanya, beradasrkan Peraturan Pemerintah No 50 Tahun $2012 \ldots$ ". $\left(R_{2}\right)$

Pendapat informan mengenai Siapa yang bertanggung jawab dalam menerapkan persyaratan legal diperusahaan ini adalah sebagai berikut:

“...Tentu Saja yang bertanggung jawab, direksi atau direktur, kemudian saya sebagai manager dan seluruh yang terkait dengan organisasi K3 diperusahaan ini...”

“...Direktur atau Direksi, Manager dan seluruh struktur anggota K3...”

Pendapat informan mengtenai program K3 telah sesuai dengan peraturan perundangan K3: “...Kita masih menyesuaikannya semua, karena program K3 diperusahaan ini masih bayak yang harus direncanakan dan dibenahi lagi..." $\left(R_{1}\right)$

"iya, sesuai dengan peraturan undang-undang yaitu PP tadikan yang no 50 tahun $2012 \ldots . "\left(R_{2}\right)$

Pendapat Informan mengenai kendala yang dihadapi perusahaan pada saat menjalankan program K3 adalah sebagai berikut:

“....Banyak kendala yang dihadapi untuk menjalankan program K3 terutama kendalanya terdapat pada pekerja atau karyawan. Butuh sosialisai yang prosesnya begitu panjang, hingga sampai saat ini masih banyak karyawan yang belum patuh sepenuhnya dengan program $K 3$ yang ditetapkan disini..." $\left(R_{1}\right)$ 
“...Kendala dalam setiap kegiatan pasti adalah, yang paling sering terjadi kendala adalah pada individu masing-masing atau karyawan kita, masih banyak yang susah untuk mengikuti program K3 diperusahaan ini... " $\left(R_{2}\right)$

Pendapat Informan mengenai yang termasuk bagian dari program K3 diperusahaan adalah sebagai berikut:

“...Program K3 yang ada diperusahaan ini, Medical Check UP bagi karyawan sekali setahun, memberikan APD bagi karyawan dan mendaftarkan karyawan menjadi anggota BPJS Ketenagakerjaan... " $\left(R_{1}\right)$

"Programnya yang pertama diberikan APD, Cek Kesehatan karyawan sekali dalam setahun..." $\left(R_{2}\right)$

Pendapat informan mengenai keterlibatan seluruh pihak di perusahaan ini, pekerja dan tamu untuk melaksanakan seluruh program K3 adalah sebagai berikut:

“...Ada, Yang saya bahas disini tamu saja y, kalau untuk pekerja sudah kita jelaskan tadi, ketika tamu perusahaan datang, dan memasuki daerab produksi, maka pihak kami memberikan APD seperti sepatu, baju dan Helm. Agar tamu yang berkunjung merasa nyaman dan aman. Atau jauh dari ancaman yang pata mengakibat kecelakaan kerja. Inti kita saling bekerja sama agar program $K 3$ berjalan dengan baik... " $\left(R_{1}\right)$

“...Iya, ada. Untuk Pekerja sudah jelaskan tadi, difasilitasi perusahaan APD, kalau untuk tamu akan difasilitasi juga APD jika dia memasuki daerah-daerah tertentu, seperti biasanya tamu selalu dating kebagian produksi, maka kami menyediakan sepatu, topi dan baju..."

Pendapat Informan mengenai pengecekan secara berkala terhadap program K3 yang diterapkan di perusahaan ini adalah sebagai berikut:

“...Dengan melihat setiap laporan pertiga bulan disitulah akan kami lakukan pengecekan secara berkala. Pengecekannya dilakuan sekali dalam tiga bulan ... " $\left(R_{1}\right)$

“...Dilakukan per triwulan pengecekan secara berkala..." $\left(R_{2}\right)$

Apapun yang menjadi alasan tidak terlaksananya K3 secara penuh di seluruh aspek kegiatan Perusahaan, hal tersebut harus tetap diupayakan dan ditingkatkan, mengingat banyaknya risiko yang ada di lapangan atau di PKS. Risiko bahaya di setiap bidang sangat banyak, baik berupa risiko paparan bahaya kimia, kebakaran, radiasi dan sebagainya sehingga penting bagi seluruh elemen yang ada di perusahaan memiliki kesadaran akan pentingnya penerapan K3. Hal tersebut dapat terwujud melalui komitmen bersama yang diawali oleh pucuk pimpinan untuk kemudian diterapkan secara menyeluruh baik kepada jajaran manajemen, karyawan dan pengunjug.

Penerapan SMK3 di perusahaan tersebut ditandai dengan dibangunnya komitmen manajemen terhadap keselamatan dan kesehatan para pekerja. Hal tersebut dibuktikan dengan pembentukan P2K3 berdasarkan SK dari direktur atau direksi pada bulan September Tahun 2017 yang menyatakan bahwa panitia pelaksana keselamatan dan kesehatan kerja diketuai oleh Manager. Dengan dikeluarkan SK direktur tersebut, maka Struktur Organisasi P2K3 dinyatakan resmi dibentuk dan dijalankan oleh personil-personil yang tergabung didalam struktur organisasi 
P2K3. Posisi P2K3 berada dibawah general manager dan termasuk sebagai pengendalian mutu produksi.

Tujuan SMK3 adalah menciptakan suatu Sistem Keselamatan dan Kesehatan Kerja di tempat kerja dengan melibatkan unsur manajemen, tenaga kerja, pihak ketiga yang terkait dengan kegiatan perusahaan kondisi dan lingkungan kerja yang terintegrasi dalam rangka mencegah dan mengurangi keselakaan dan penyakit akibat kerja serta terciptanya tempat kerja yang aman, efesien dan produktif. Ruang lingkup SMK3 meliputi aktifitas yang ditetapkan terhadap sasaran dan target keselamatan dan kesehatan kerja dengan memfokuskan pada perencanaan kegiatan pertanggung jawaban, tujuan dan jangka waktu yang ditetapkan perusahaan.

Ditinjau dari hasil peninjauan data yang diperoleh dapat diketahui bahwa penerapan Kebijakan K3 dan Perencanaan K3 yang berpedoman pada PP No 50 Tahun 2012 adalah komitmen manajemen perusahaan dalam penerapan K3 diwujudkan dengan membentuk Struktur Organisasi P2K3. Komitmen dalam penerapan Keselamatan dan Kesehatan Kerja telah tertulis dan ditandatangani oleh direktur perusahaan, namun belum sepenuhnya berjalan dengan efektif. Berdasarkan pernyataan pihak pengelola, hal ini masih dalam persiapan. Komitmen juga diwujudkan dalam bentuk penyediaan anggaran khusus untuk penerapan keselamatan dan kesehatan kerja dan personil-personil yang khusus menangani masalah-masalah K3.

Komitmen yang nyata dari pihak pimpinan dapat terwujud dengan penyediaan anggaran khusus untuk pelaksanaan program K3. Sebab mustahil suatu program dapat terlaksana tanpa adanya anggaran. Oleh sebab itu, penting bagi pihak manajemen perusahaan untuk mengkomunikasikan kepada seluruh karyawan perusahaan untuk bersama-sama berkomitmen menerapkan K3 di perusahaan ini. Sesuai dengan pedoman penerapan SMK3 yang dikeluarkan oleh pemerintah dalam PP No. 50 Tahun 2012 yang menyatakan bahwa Komitmen di wujudkan dalam bentuk kebijakan tertulis, jelas dan mudah dimengerti serta diketahui oleh seluruh karyawan.

Komitmen Kebijakan K3 telah ditetapkan dan masih dalam proses pembenahan yang lebih baik lagi untuk mewujudkan sarana dan Prasarana serta SDM yang lebih baik untuk melaksanakan K3. Namun diakui bahwa sarana dan prasarana yang tersedia masih minim. Misalnya dalam perlengkapan untuk Program K3 masih dalam proses pembenahan yang lebih baik. Ketersediaan dana yang sangat minim mengakibat kegiatan program dan kebijakan K3 terhambat dan pekerja yang masih banyak tidak paham tentang K3 serta kesadaran pekerja dalam pemakaian APD pada saat bekerja dengan berbagai alasan ketidaknyamanan memakai APD pada saat bekerja.

Semua anggota yang ada di struktur organisasi P2K3 terlibat dalam perencanaan kebijakan K3 dalam bentuk sumber daya yang berupa manajer dengan sertifikat pelatihan K3 Umum dan Karyawan yang mendapatkan Pelatihan K3 dikarenakan anggota yang terstruktur di organisasi K3 bukan bidang Keselamatan dan Kesehatan Kerja dan juga sarana yang diperlukan dalam bidang K3. Peninjauan ulang kebijakan K3 dilakukan per tiga bulan atau triwulan. Pada saat melakukan laporan triwulan P2K3. Berdasarkan triagulasi sumber data yang diperoleh, dapat diketahui bahwa penerapan kebijakan K3 di Perusahaan belum mencapai standar, baik yang berpedoman pada PP No 50 Tahun 2012.

Identifikasi bahaya adalah upaya sistematis untuk mengetahui potensi bahaya yang ada dilingkungan kerja. Dengan mengetahui sifat dan karakteristik bahaya, kita dapat lebih berhatihati, waspada dan melakukan langkah-langkah pengamanan agar tidak terjadi kecelakaan. Namun demikian, tidak semua bahaya dapat dikenali dengan mudah. Identifikasi bahaya dan penilaian risiko harus dilakukan pada seluruh aktivitas (rutin, non rutin dan kontraktor serta pengunjung), faktor-faktor manusia, bahaya yang berasal dari luar perusahaan, bahaya yang ditimbulkan oleh 
perusahaan, infrastuktur, material dan peralatan dari perusahaan lainnya, perubahan prosedur kerja, pengembangan SMK3 terhadap kemungkinan terjadinya perubahan pada sistem operasi, peraturan yang berhubungan dengan implementasi pengendalian dan disain tempat kerja proses, instalasi, mesin/peralatan, prosedur operasi dan perusahaan kerja serta adaptasinya kepada manusia. ${ }^{6}$

Pihak perusahaan melakukan penentuan konteks bahaya dan mengetahui cara untuk mengurangi potensi bahaya dilapangan. Adanya pengenalan potensi bahaya ditempat kerja terlebih dulu, kemudian dilakukan pengendalian. Setelah pengendalian tersebut dapat dikatakan aman, maka dapat aktivitas kerja dinyatakan aman. Pihak perusahaan melakukan penentuan konteks bahaya dan mengetahui cara untuk mengurangi potensi bahaya dilapangan. Dan pihak perusahaan menggunakan teknik untuk menentukan potensi bahaya dengan metode HIRARC

Perencanaan K3 disetiap perusahaan penting dilakukan mengingat banyaknya hal yang harus dilakukan, sehingga melalui perencanaan yang baik semuanya dapat terlaksana. Tanpa perencanaan K3 yang baik akan sulit mengidentifikasi dan melaksanakan program yang benarbenar harus diprioritaskan untuk dilaksanakan. ${ }^{7}$

Ditinjau dari pedoman SMK3 menurut PP No 50 Tahun 2012, ditetapkan bahwa perencanaan K3 yang sesuai dengan persyaratan harus mempertimbangkan hasil penelaah awal, identifikasi potensi bahaya, penilaian risiko dan pengendalian risiko, kemudian merumuskan suatu program dengan tujuan yang jelas. ${ }^{6}$ Perusahaan mengidentifikasi dan menentukan peraturan atau persyaratan K3 yang sesuai dengan prosedur K3 dan SMK3 yang diterapkan perusahaan. Informasi peraturan yang akan dipakai oleh perusahaan harus terus diperbaharui dan disosialisasikan kepada seluruh pekerja dan pihak lain yang terkait, seperti tamu perusahaan.

Tujuan dan program K3 di perusahaan didokumentasikan sesuai fungsi dan tingkatan yang ada di organisasi perusahaan. Tujuan dan program kerja K3 yang disusun harus bisa diukur, diaplikasikan, dan konsisten atau sesuai dengan kebijakan yang berlaku tentang K3 di perusahaan, serta mencakup seluruh risiko yang ada di tempat kerja. Selain itu tujuan dan program K3 yang disusun juga harus mempertimbangkan teknologi, pembiayaan, orientasi bisnis, dan operasional perusahaan.

Penerapan Kebijakan dan program K3 di perusahaan tersebut diterapkan sesuai dengan undang-undang yaitu Peraturan Pemerintah No 50 Tahun 2012. Dalam Pembentukan program K3 yang bertanggung jawab dalam menerapkan persyaratan legal adalah direktur atau direksi, manager selaku penanggung jawab K3 dan seluruh anggota yang terkait didalam struktur organisasi P2K3. Dalam penerpan program K3, program tersebut tidak berjalan dengan baik. Kendala yang terjadi terdapat pada pekerja atau karyawan yang belum sepenuhnya mengetahui tentang pentingnya K3. Sehingga perlu pihak perusahaan melakukan sosialisasi yang lebih baik lagi kepada karyawan dan pemantauan yang semaksimal mungkin. Supaya program K3 yang telah direncanakan berjalan dengan baik. Program K3 diperusahaan ini adalah medical check up dalam periode sekali setahun bagi karyawan, memberikan APD kepada karyawan dan mendaftarkan karyawan menjadi anggota BPJS Ketenagakerjaan. ${ }^{8,9}$

Apapun yang menjadi alasan tidak terlaksananya K3 secara penuh di seluruh aspek kegiatan perusahaan, hal tersebut harus tetap diupayakan dan ditingkatkan, mengingat banyaknya risiko yang ada di lapangan atau di PKS. Seperti telah dipaparkan pada tinjauan pustaka bahwa risiko bahaya di setiap bidang sangat banyak, baik berupa risiko paparan bahaya kimia, kebakaran, radiasi dan sebagainya. Sehingga penting bagi seluruh elemen yang ada di perusahaan memiliki kesadaran akan pentingnya penerapan K3. Hal tersebut dapat terwujud melalui komitmen bersama 
yang diawali oleh pucuk pimpinan untuk kemudian diterapkan secara menyeluruh baik kepada jajaran manajemen, karyawan dan pengunjug. ${ }^{10}$

\section{KESIMPULAN}

Berdasarkan hasil analisis data, dapat ditarik kesimpulan mengenai penerapan kebijakan dan perencanaan Keselamatan dan Kesehatan Kerja di Perusahaan pengolahan kelapa sawit tersebut yakni komitmen dan kebijakan manajemen perusahaan terhadap penerapan K3 telah ada tertulis, namun belum tersosialisasikan secara menyeluruh kepada pekerja di perusahaan maupun Pengunjung perusahaan, perencanaan K3 hanya beberapa yang telah dilaksanakan yaitu diantaranya dengan mengidentifikasi secara awal permasalahan-permasalahan K3 yang kemudian disusun program berdasarkan prioritas permasalahan tersebut, organisasi K3 di perusahaan telah dibentuk dan telah melaksanakan tugas dan fungsinya masing-masing, namun personil yang menjalankan organisasi tersebut belum mencapai kriteria sesuai dengan latar belakang Keselamatan dan Kesehatan Kerja, penerapan K3 di perusahaan telah berjalan, namun belum seluruhnya program terlaksana, misalnya minimnya dana yang tersedia sehingga penyediaan alat perlindungan diri yang diberikan kepada pekerja yang bekerja di lapangan sangat minim. 


\section{DAFTAR PUSTAKA}

1. Rosdiana W. Sistem Manajemen Keselamatan dan Kesehatan Kerja (SMK3) di PT. PERTAMINA (PERSERO) Unit Pemasaran II Terminal Bahan Bakar Minyak (TBBM) Jambi. 2012;

2. Maulana R, Hamid D, Mukzam MD. Pengaruh Keselamatan dan Kesehatan Kerja Terhadap Kepuasan Kerja Karyawan (Studi Pada Karyawan Bagian Pabrikasi Pabrik Gula Kebon Agung Malang). J Adm Bisnis. 2015;13(09):112-24.

3. Sucipto CD. Keselamatan dan Kesehatan Kerja. 1st ed. Jakarta: Goysen Publishing; 2014.

4. Pangkey F, Malingkas GY, Walangitan DOR. Penerapan Sistem Manajemen Keselamatan dan Kesehatan Kerja (SMK3) Pada Proyek Konstruksi di Indonesia (Studi Kasus:

Pembangunan Jembatan Dr. Ir. Soekarno-Manado). J Ilm MEDIA Eng. 2012;2(2):100-13.

5. Mukti, Dewantoro Ratno NR. Implementasi SMK3 dengan Melakukan Evaluasi. J ENVIROTEK. 2012;9(2):1-4.

6. Ramli S. Pedoman Praktis Manajemen Risiko dalam Perspektif K3. 1st ed. Jakarta: Dian Rakyat; 2010.

7. Agustini RR, Rimantho D. Penentuan Prioritas Strategi Pengelolaan K3 Proyek Pemasangan Pipa Gas Menggunakan Pendekatan Metode AHP. J Tek Ind. 2018;19(2):107.

8. Fitriana L, Wahyuningsih AS. Penerapan Sistem Manajemen Keselamatan dan Kesehatan Kerja (SMK3) di PT. Ahmadaris. HIGEIA (Journal Public Heal Res Dev [Internet]. 2017;1(1):29-35. Available from: https://journal.unnes.ac.id/sju/index.php/higeia/article/view/14004

9. Yuliandari D. Perlindungan Tenaga Kerja Terhadap Kecelakaan Kerja di Bidang Jasa Konstruksi Melalui BPJS Ketenagakerjaan di Kota Palembang [Internet]. Universitas Lampung; 2019. Available from: http://digilib.unila.ac.id/55428/3/TESIS TANPA BAB PEMBAHASAN.pdf

10. T. Lestari ET. Hubungan Keselamatan dan Kesehatan (K3) dengan Produktivitas Kerja Karyawan (Studi Kasus: Bagian Pengolahan PTPN VIII Gunung Mas, Bogor). J Manaj [Internet]. 2009;1(1):73-9. Available from: file://G:/PUBLICATION/national public health journal/K3/refrensi jurnal sylvia/1601-2575-1-PB.pdf 